\title{
Anorectal Infection
}

National Cancer Institute

\section{Source}

National Cancer Institute. Anorectal Infection. NCI Thesaurus. Code C78174.

An infectious process affecting the anal area and the rectum. 